\title{
Globalizing Global Skill Partnerships and Africapitalism as a sustainable aid response to the irregular migration crisis between Cameroon and Europe.
}

\author{
Mbuih Zukane Retruyap \\ Institute of Development Policy, \\ University of Antwerp, Antwerp, Belgium
}

\begin{abstract}
Discourses on skilled workers' migration from Africa to Europe was enthralled around brain drain. Today, the trend is more focused on brain waste as a good number of irregular skilled migrants are obliged to do mean jobs abroad. My main argument focuses on the demand and supply of skilled labor. Building on the fact that in 2050, $34 \%$ of Europe's population will be made up of 60+ (demand), while Africa will have 800 million youths (supply). Following this trend, a global partnership scheme for migrants is vital in managing skilled migrants through training and complementarity, thereby regulating the issues around irregular migration. I proposed the usage of Africapitalism as a new modus operandi that the EU will use as an alternative to solve the root causes of irregular migration.
\end{abstract}

Keywords: migration, development, aid, GSP, africapitalism

\section{INTRODUCTION}

According to the 2017 UN report on migration, the world counted 258 million migrants in 2017, with 78 million of them living in Europe. Likewise, 29.5 million asylum seekers were counted in 2016. Modern transport, ICTs, especially the social media has played a significant role in this escalation in mobility, fostered by income and wage differences between the two ends. Forced displacement experienced an upsurge after the 9/11 terrorist attack in the USA and eventually the 2010/2011 Arab spring. Progressively, there is a perception shift from perceiving migrants as a liability to migrants as assets, especially when the right policies are adopted, reason why migrants contribute substantially to economic growth and development. For instance, in 2016 alone, migrants from developing countries sent home 413 billion US\$ in remittances (OECD, 2017). Likewise, migrants supply labor in receiving countries, pay taxes, contributes to technological advancement and diversity. It is against this backdrop that target 10.7 of the 2030 SDG concentrated on inclusive migration policies, after which the UN General Assembly adopted the New York declaration on migration and refugees on 16 September 2016. Looking at the growing importance of implementing inclusive migration policies on development, I decided to elaborate this write up on how sustainable migration policies can be achieved between Cameroon and the EU. The Global Skill Partnership (GSP) so far is one of the most acceptable alternatives for an inclusive and participatory migration. To make it worthwhile I proposed the usage of Africapitalism as a model that can be used as a localised add-on to GSP, which can perfectly work in consortium with the European Union Trust Fund for Africa (EUTFA) to reinforce migrants' skills through specialized training and know-how (for inspiring migrants) and to build entrepreneurship skills to 'migrants' willing to go back home (returnees). This has to be demand and supply driven, reason why I proposed city-to-city twinning as a modus operandi to achieve a more inclusive and glocalized GSP between Cameroon and Europe. This will have a longterm positive consequence because it is estimated 
that by 2050, Europe's population will be essentially a third age population with $34 \%$ made up of 60+, while Africa will have an estimated 800 million youths (labor force) (Clemens \& Postel, 2017).

For a better understanding of sustainable migration, this study explores the tenets and motivation behind illegal emigration from Cameroon to Europe among youths. A spasm on migration policy as it prevails currently is equivalent to reducing aid level by $24 \%$ (Berthélemy, Beuran, \& Maurel, 2009) . Nowadays, there are a lot of debates on how aid can develop less developed economies, and a consensus is yet to be found and agreed upon, especially looking at the intentions and purposes of aid (Carbone, 2013), and whether aid can deter or foster irregular migration (Clemens \& Postel, 2017) in our world which is increasingly versatile. The central debate in this academic write up beside questioning aid effectiveness also explores the tenacity of Global Skill Partnerships (GSP) ${ }^{1}$ as an alternative solution in handling migration crisis. GSP which entails outsourcing technical know-how by offering specialized training to migrants falls under technical cooperation. If implemented, GSP demystifies the current literature on immigrants, who are generally regarded as an encumbrance in the receiving country. I then propose Africapitalism as a GSP model that will create an attractive and enabling environment for return migrants and migrants wishing to depart. My premise, therefore, is to adopt an African economic empowerment initiative (Africapitalism), while capitalizing on skill creation and liberal skilled labor movements (GSP) within a globalized arena.

After presenting the methods used, the first part will be dwelled on ***

\section{METHOD}

This write up explores desk search, specifically on a review of literature related to the prevailing migration-aid-development discourse and the new alternatives (GSP and Africapitalism). This will be achieved through search in major databases like google scholar, academic search and web of science, with the search phrase being made up of migration and development, aid and poverty alleviation, Africapitalism and decentralized cooperation for development GSP. Besides the review, primary data were obtained basically through life history interviews, phone calls (computer-assisted telephone interviews (CATI), the usage of social media-based focus group discussions and non-participant observation. Thus snowball sampling was used to get to key informants. I interviewed 12 beneficiaries of the TEEP (implementers of Africapitalism) as well as two 'local migration officers' (traffickers) in Cameroon, 15 irregular migrants in Belgium, Spain and France as well as 11 'slave' returnees from Libya. I also interviewed 2 migration experts, one in OECD, Paris and one in the EU commission. All the data collected are analyzed using the Nvivo 11 pro software.

\section{Migration and aid, two intertwined concepts}

According to $\mathrm{IOM}^{2}$, Migration is intertwined with geopolitics, trade and cultural exchange, and provides opportunities for States, businesses, and communities to benefit enormously in today's interconnected world. Because of the differences in income and wage rates as well as the interconnectedness mentioned earlier, an osmosis effect is created, where stronger states

1 http://www.oecd.org/dev/development-posts-global-skill-partnerships-a-proposal-for-technical-training-in-amobile-world.htm accessed on 10/03/2018 at 19:56

${ }^{2}$ The International Organization for Migration is an intergovernmental organization that provides services and advice concerning migration to governments and migrants, including internally displaced persons, refugees, and migrant workers. Source: https://en.wikipedia.org/wiki/International_Organization_for_Migration accessed on $\underline{10 / 03 / 2018}$ at $21: 24$ 
attract weaker ones (Lucas, 2005) but at the same time most stronger states prefer to empower the weaker ones by treating the root causes of their departures because they are often considered to create disequilibrium and a disruption of social norms. This explains why the two concepts are intertwined.

Likewise, since the 2015 migration upsurge with more than 1.25 million refugees recorded as forced displaced persons (Greussing \& Boomgaarden, 2017), more aid policies especially between Europe and African countries are geared towards regularizing illegal migration and curing the 'root causes' of migration as Clemens and Postel (2017). This trend which is as a result of forced displacement is again more difficult to handle, creating the general believe that aid will hardly solve departures problems. That is why Clemens and Postel (2017), argue that aid targeting youth employment in the country of origin only reduces migration urge for a very short term, owing to the fact that as income level rises, migration urge also rises proportionately. Furthermore, aid projects should be demand driven, not mechanic as is always the case, this will permit to see if it meets with the aspirations of the migrants (Bermeo \& Leblang, 2015).

In this migration-aid debate, there are a plethora of school of thoughts, others think that aid can deter irregular migration (Gaytan-Fregoso \& Lahiri, 2000), while others are adamant on the point that nothing, not even aid will stop people from migrating (De Haas, 2008). Other pundits are for the fact that aid policies on migration should be geared towards enforcing border controls of the receiving countries (Cornelius, 2001). In this regards, I shall crossexamine the relationship between aid and migration under three line of thoughts and literature - foreign aid as a tool to increase development in sending and receiving countries, the influence of already settled migrants on aid and remittances, and conservationists who want aid money to reinforce border controls, as follows:

\section{Foreign aid as a tool to increase development in sending countries}

On 16 October 2013, after a migrants boat sank off the coast of Lampedusa, Italy, Jose Manual Barroso said the EU must increase aid actions to improve on the living conditions of the countries of origin (Parsons \& Winters, 2014). This is the panacea according to most countries, yet such perceptions have been existing for so many decades without any major change. According to Clemens and Postel (2017, p. 4), each migrant who successfully enters physically in a country, generally leads to a $\$ 242$ increase in the development assistance of the country of origin. In this light, therefore, Vázquez and Sobrao (2016), argues that Spain can be cited as a glaring example, where a 1\% increase in the migrant population leads to an $18 \%$ increase in Spanish foreign aid to the country of origin.

The EU currently is the biggest donor in the world, providing over $50 \%$ of aid to its partners, all these are lodged within the 2006 European consensus on development ${ }^{3}$. According to the EU commission, Each year, the EU provides about 50 billion in aid. In 2016 alone, the EU provided 18.63 billion on development aid ${ }^{4}$ with a greater chunk offered in the EU-ACP program. The aim of this is to develop countries of departures, thus limiting the number of migrants in what De Haas (2010) describes as shortcut solutions to immigration.

\footnotetext{
3 European Parliament council resolution No 2006/C 46/01 of 24/02/2006

${ }^{4}$ https://euaidexplorer.ec.europa.eu/ accessed on 04/03/2018 at 10:10 a.m.
} 


\section{Already settled migrants lobby for more aid in their country}

Already settled migrants play a dual role in aid, through lobbying for more aid in their home country and also providing assistance via remittances (Clemens, Özden, \& Rapoport, 2014). They easily get connected with donor agencies in their country of settlement and liaise them with the needs of their home country. Besides lobbying for aid, most migrants group themselves into associations, and structures which provide assistance back home (Lacomba \& Cloquell, 2014). Migrants easily get connected and lobby for funds for development back home, making it easier for them to orientate aid. In 2016 alone, migrants from developing countries sent home 413 billion US\$ in remittances.

Another key role already settled migrants play is that they easily facilitate other family members to migrate. They provide the resources and information in this regard (De Haas, 2008). Data from OECD (2017) shows that middle-income countries have more migrants and asylum seekers than low-income countries (Clemens et al., 2014). In this regard, I am prompted to say that the more a country receives assistance, the more the nationals will have the means and resources to migrate (Clemens \& Postel, 2017; Bameo \& Leblang, 2015; OECD, 2017). Economic growth in less developed countries is thus positively correlated to emigration.

\section{Conservationists seek the usage of aid to reinforce border control}

President Trumps 'Mexican wall' polemics translate the anti-globalization way of thinking. As proponents of this ideology advocate that aid should, first of all, treat the borders, before going elsewhere (Geddes, 2005). Though such policies to an extent have succeded to tighten access into the destination countries of irregular migration, it has produced some adverse effect like the creation of niches and camps of illegal migrants, like in Calais (France) and in Lampedusa (Italy) which is another bone of contention. The EU, through the External border fund, invested overall, EUR 1820 million over the period 2007-13 on border security and control, yet illegal migration reached its peak in 2015. The solution, therefore, is not on tightening borders, but on seeking collective action in managing migration crisis (Bermeo \& Leblang, 2015).

It is against this backdrop that new EU funds and projects are geared towards a fair management of migration like the Asylum, Migration and Integration Fund (AMIF) for the period 2014-20, with a total of EUR 3.1 billion for the seven years, the Solidarity and Management of Migration Flows (SOLID), the European Fund for the Integration of Third Party Nationals (EIF), just to name these. With a blend of Africapitalism, a deeper perspective on deterring and managing illegal migration can be achieved.

\section{The geopolitics of migration and aid}

Most studies in recent years reveal that migration and aid are two words with very high geopolitical stakes (Parsons \& Winters, 2014). The migration-aid connection is very high between a colonial master and its former colonies, on one hand, migrants from the former colonies solicit more to migrate into the colonial power's territory (Lucas, 2016). Likewise, most former colonizers privileges their former colonies in development assistance and aid than elsewhere. Migration and aid are also determinant factors in most regional integration agreements (Arts \& Dickson, 2010). Thus, there is a power relation when it has to do with international migration, thus, each category and categorization of migrant always has geopolitical undertones (Allen et al., 2017) and aid trends also follows this pattern, especially when we dwell on the fact that an increase in immigration and asylum-seeking leads to an increase in aid in the country of departure, thus constant alteration of laws and policies related to migration. 


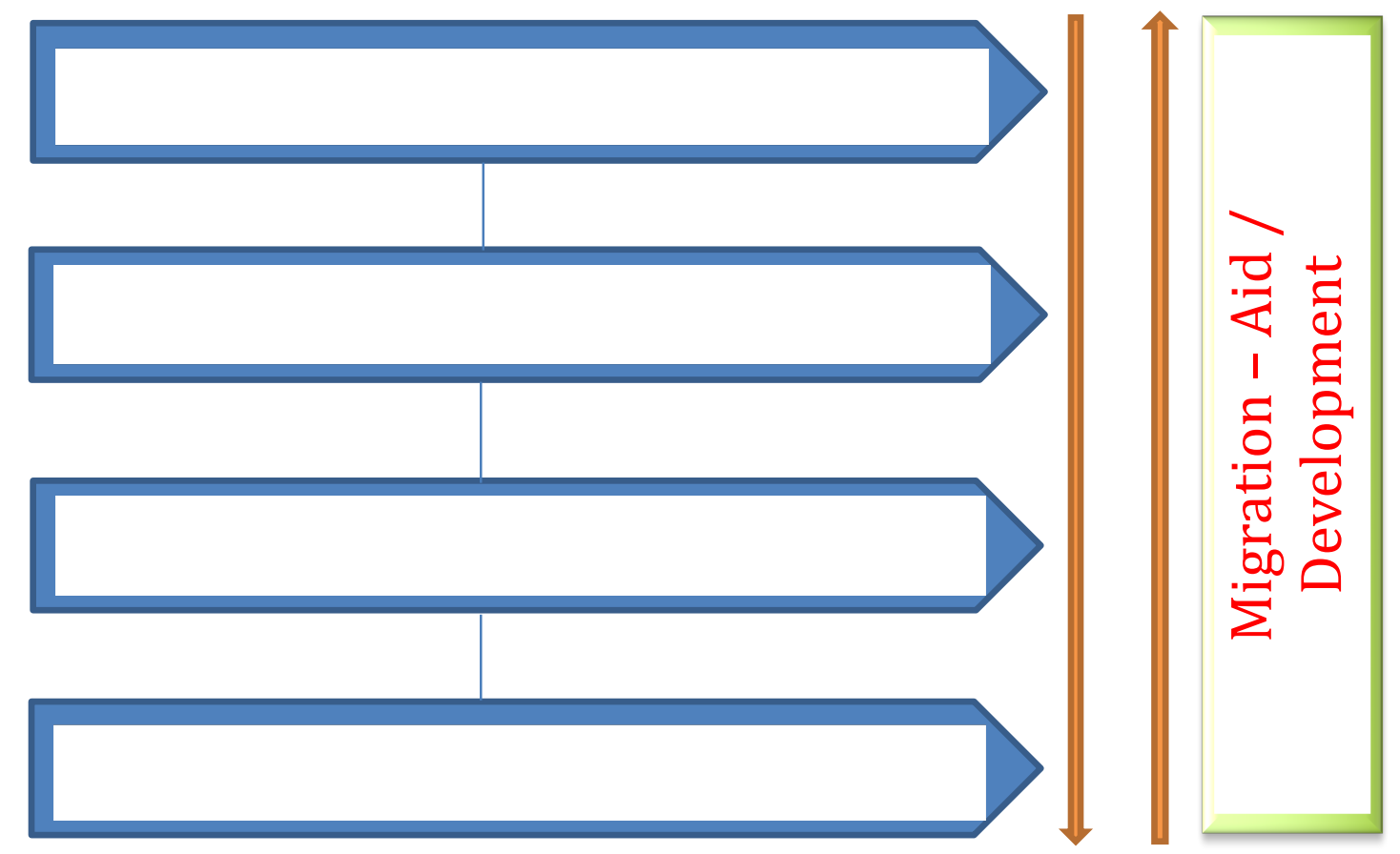

Diagram showing a summary of the literature on migration-aid and development (source: author).

\section{Causes of Migration - What spurs young Cameroonians to indulge in irregular migration? (push and pull factors for migration).}

According to Lucas (2016), people migrate because of differences in wage and income between two locations, that is why people migrate from low income to high-income location, which explains the rationale of Cameroonians migrating to Europe among other reasons. Migration whose common definition is the movement of people from one place to another, in reality, is more complex than it sounds. People migrate for different reasons and expectations, but generally, their rationale can be grouped under economic factors, but also by social, political, cultural, environmental, health, education, and transportation factors (Thet, 2014).

Building on the complex nature of migration, theories were developed to substantiate on migration (Lee, 1966). Migration as a concept has changed drastically from the classical theories to the new theories, including the neoclassical economic theory, the dual labor market theory, new economics of labor migration theory, relative deprivation theory, world system theory and the osmosis theory ${ }^{5}$. Global migration flows has been escalating at a very fast rate in recent years because of the plethora of upheavals and awareness as presented below:

\section{The international climate}

Cameroonian polity over the years created an enabling environment on migration. Firstly, Cameroon is partisan to a plethora of international conventions related to migration like the 1949 ILO Migration for Employment Convention, ratified by Cameroon in 1962, the 1961 Refugee Convention, ratified by Cameroon in 1961, the 1967 Refugee Protocol ratified in 1967, the 1975 ILO Migrant Workers Convention ratified in 1978, the 2000 human trafficking protocol and Migrant Smuggling Protocols, both ratified in 2006. This enabling environment paved the way to about 291792 migrants in 2013, with 162411 made up of males and 129 381 made up of females. In this same year, the top 5 countries of destination are France 6451 , Germany 5005, Italy 2501, USA 1627, South Africa 1118 (IOM, 2015). 
The majority are long-term migrants given that $40 \%$ reside in their country of emigration for over ten years, and 16\% for a period of five to ten years (OECD, 2008). Concerning asylumseekers, Cameroon attained an apogee of 6,289 in 2003, mainly because of the Southern Cameroon National Council secessionist movements that were fiercely countered by the Cameroon Government. Their number progressively declined during the following years to around 2,933 in 2008, mainly in Europe (Belgium, France, Germany, the Netherlands, Switzerland) (UNHCR, 2009).

Cameroon has a significant number of highly skilled emigrants. In $2000,17 \%$ of the Cameroonian population with a higher education emigrated (Artuç, Docquier, Özden, \& Parsons, 2015). During the 1995-2005 period, 46\% of Cameroonian doctors and 19\% of nurses emigrated to selected countries (Clemens \& Pettersson, 2008). According to the Cameroon Medical Association, 4,200 Cameroonian doctors, mostly specialists, are working abroad. Only 800 , that is 1 for 10,000 to 20,000 inhabitants, are left in the cities, with 1 for 40,000 to 50,000 in the distressed areas. It is believed that 20,000 African nurses and doctors emigrate to countries of the north every year (Clemens \& Pettersson, 2008).

\section{The political and legislative climate}

Some few years back, Cameroon was often referred to as a peaceful island in the troublesome central African sub-region (Zukane \& Tangang, 2017). This comparison, in reality, was just relatively to its central African neighbors. In reality, the country for over 60 years has been plaque into a series of political crisis, including the 1984 coup, the 1990 upheavals (Takougang \& Krieger, 2000), the 2008 uprising and recently the Anglophone crisis which started in November 2016. These crisis has led to massive migration of young Cameroonians for fear of persecution, especially the Anglophone minority. Besides these political upheavals, the nation is also reputable for bad governance. Cameroon was ranked the most corrupt country in the world by transparency international in 1999 and since then features in the top $10 \%$ of global corruption ranking (Fombad, 2000) and this poor governance has a trickle-down effect on migration because the porousness of the state's control and protection, makes young startups to be vulnerable in the hands of government officials and most cases, youths prefer to use their startup capital for migration

\section{The role of the media}

Most of the mainstream media from my perspective contributes to the misrepresentation of Europe, which spurs youths to migrate to also 'live' in the paradise they see over the media. Some of the media in a bit to report on migration issues ends up rather giving information on how it happens. The media's role is to inform and propagate information, which is what they do and which ends up giving and idea on how to migrate. With the current advent of new media outlets like the social media, young persons easily get information on how to go about the illegal migration. According to (Dekker \& Engbersen, 2014), social media facilitates migration in a myriad of ways.

"First, they enhance the possibilities of maintaining strong ties with family and friends. Second, they address weak ties that are relevant to organizing the process of migration and integration. Third, they establish a new infrastructure consisting of latent ties. Fourth, they offer a rich source of insider knowledge on migration that is discrete and unofficial".

This clearly elucidates the power of the social media and what role it plays in migration, there is a misrepresentation of the 'Eldorado' and the 'do or die migration' narratives of young Cameroonians 


\section{Remittances}

Remittances are money sent by migrants back to their home country. According to the World Economic Forum report of 2016, remittances reached record levels in 2014, with a way over $\$ 436$ billion being sent to developing countries. Overall global remittances totaled $\$ 582$ billion in 2015. These remittances are a source of motivation for irregular migration, because as the saying goes, if others did it, why not everybody?. Over the past years, remittances have been flowing in steadily and are poised to be the number one source of foreign inflow of money in developing countries, in an equal par with aid (Gupta, Pattillo, \& Wagh, 2009).

\section{Economic reasons}

It is very astonishing but true that 10 African countries are poorer today than was the case before independence. In the same vein, the GDP per capita growth of 20 countries from 19802000 was at 0 growth rate 6 . This economic snag which is linked to bad governance (Acemoglu \& Robinson, 2013) created a lot of inequalities and disparities between most African countries and the developed countries. These national loopholes and incapability has far-reaching repercussions at the grassroots levels, as it generally engenders poverty (Barro, 1991), followed by unemployment, fluctuating prices, weak markets and consumerism (Dollar, 1992). In most cases, like in Cameroon, $79 \%$ of the population relies on what nature offers, there is inadequate transformation, making the country to be constantly poor.

\section{Alternatives to deleterious migration and aid dichotomy}

While contemporary policies are in favor of using aid as a deterrent of migration at its source, a growing wave of thought are in support of the fact that both are not only complementary, but that aid should be used rationally in support of the unstoppable mobile world. That is why the OECD and CGDEV7, proposed the Global Skill Partnership (GSP) as a response and alternative to migration ills within a globalized perspective. Likewise, I intend to develop Africapitalism as African based model which can supplement the GSP.

\section{The Global Skill partnership (GSP)}

OECD (2017) defines "[a] GSP [as] an upfront agreement between employees and/or governments in destination countries and professional training center in origin countries". In this same regards, (Clemens, 2015) regards GSP as "a bilateral public-private partnership to link skill creation and skill mobility in a mutually beneficial and equitable way". He further argues that when skilled workers migrate, the act is often referred to as brain drain in the country of origin, meanwhile, in some cases, they have shunned abroad and treated as illicit migrants and at times waste their talents or take a very long time to integrate the society.

Tenets of GSP adapted from Clemens (2017)

- The training framework should be demand and supply driven by needs assessed and easy visa policies for students.

- A common biometric system and database to check and control migrants certificates and qualifications in both ends.

- Skills shortage and availability in both ends should continuously be updated and training in sending countries should be on a continuous basis.

- Startup Capital should be made available, not only for skill development but for businesses.

\footnotetext{
${ }^{6}$ https://www.theglobalist.com/economic-causes-migration/, accessed on 04/03/2018 at 23:20

${ }^{7} \mathrm{CGDEV}$ is the Center for Global Development, which is a think tank on major global development issues, especially migration
} 
- The best way to achieve an inclusive GSP is via decentralized cooperation or localization, where it is local councils that will do the skill assessment. This will permit them to have a full control over migrants (family, collateral security).

- The governance and institution should be strong or reinforced for an effective GSP.

- GSP should have a legal binding document for the proper legislature

\section{Shaping Africapitalism, as a bottom-up GSP scheme}

With regards to the lapses observed in aid/migration trends, which are often entangled with interest, top-down imposition (Clemens \& Postel, 2017), or a mechanic mechanism to continue neo-colonialism (Moyo, 2009), most researchers are thinking of alternative outlets like the GSP. As Amaeshi and Idemudia (2015, p. 3) posit, “[n]o other people from other continents can love Africa more than their own". The solution to Africa's problems lie within the continent, any other initiative will always be welcomed but will have a more far-reaching impact if its complements and supplements African led initiatives (Bank, 2006).

Not much is known about Africapitalism, because the concept was coined barely four years back, emanating from a policy speech by Tony Elumelu (Oseni \& Oseni, 2015). According to (Ikiebey, 2015) "Africapitalism, is an economic philosophy that embodies the private sector's commitment to the economic transformation of Africa through long-term investments that create both economic prosperity and social wealth". When promoted by Africa's biggest donors (EU), it can help in poverty alleviation, more rapidly than aid. This is believed by Sachs (2008) to be the only way a "poverty push" can be attained, which is today embedded in the socioeconomic philosophy of Africapitalism ${ }^{8}$, which is "a fair [enough] reward" to all stakeholders for their involvement in promoting investment and growth, mostly by Africans themselves (Oseni \& Oseni, 2015, p. 9). But when intertwined in the GSP can lead to mutual benefit on skill development as highlighted above

Promoting private business investment is not a new concept in the development literature (Amaeshi \& Idemudia, 2015), but what makes Africapitalism, different is the fact that right from its conception, it basically targets African grounded investments with some emphasis on youths and startups according to the vision of Tony Elumelu (Ikiebey, 2015) and therefore, we are arguing that European development policies will be sustainable if they hence forth have youth's startup and youth technical training as priority.

\section{Modeling Africapitalism, within the migration discourse in Cameroon.}

Enabling environment: So far the Cameroonian government has facilitated the creation of enterprises and startups. The creation of small and medium-sized enterprises in Cameroon has been made very simple, as a sequel to a prime ministerial decree on 18 May 2009. This decree created an enabling environment for the creation of specialized centers in all the major cities of the country. Thus, today, it takes just 72 hours to create an enterprise online (http://www.cfce.cm/) in Cameroon, a procedure which initially would take 3 months to 1 year ${ }^{9}$. The decree has reduced costs, bottlenecks, bureaucracy and corruption that used to be involved. The prime purpose of this action is to alleviate poverty, develop the private sector and promote small and medium-sized enterprises, which are the bedrocks of Africapitalism.

\footnotetext{
${ }^{8}$ Africapitalism is the economic philosophy that the African private sector has the power to transform the continent through long-term investments, creating both economic prosperity and social wealth. Source: https://en.wikipedia.org/wiki/Africapitalism, accessed on 27/12/2017 at 12:39 pm. Africapitalism is therefore a portmanteau of the word Africa and Capitalism

9 http://www.a54marketinggroup.com/create-your-business-in-cameroon-in-72-hours/ accessed on $05 / 03 / 2018$ at $02: 01$
} 
Financial empowerment: The Cameroon government is 2015 created a small and medium enterprise bank, which offers loans to startups in Cameroon. It is currently having over 250 projects, where they give a loan to the tune of about 2000 dollars to each person, for the loan to be re-payed back after a given period of time to the next beneficiary (revolving fund). This has been a mechanism for startup capital to young persons and has gone hand-in-gloves with the national youth plan, which is a 5 years strategic action plan to empower youths in Cameroon.

\section{Africapitalism in Cameroon: Emulating the TEEP to fit in the GSP}

- 65 beneficiaries in 3 cohorts, (incubated as a new breed of entrepreneurs who can themselves become a catalyst for further entrepreneurial-led growth.

- 1,300 direct jobs and 3,900 indirect jobs, giving an approximate total of 5,200 jobs. After receiving $\$ 10000$ (5.5 million).

- Hands-on training on a business plan, skills development and pan Africanism

\section{Translating the TEEP on the EUFTA}

- 13.3 million euros to check irregular migration

- Economic opportunities 10. Million Euros

- Return migration and reintegration 3.3 Million Euros

- 27 million euros for global resilience response.

yet...

No major change because of the status quo

- Mechanic implementation (AFD (10 Million, GIZ, 7 million...).

- Privileges philanthropy (good, but not sustainable) and government bodies (corruption, bad governance)

But....

- With Afrcapitalism, youths (migrants are the main actors)

- They will receive training and skill development

- The case of the 10 million on economic opportunity will mean 1000 euros to 10000 youths, which will create 100000 jobs

- Teach 10000 youths on pan Africanism and conscientism

\section{A question of policy recommendation}

\section{Selection}

- According to the July-August 2017 report of the IOM ${ }^{10}$, Cameroon counts 1768 migrants in Libya, a majority of whom are seeking to enter into Europe at all cost.

- Illegal migrants in major European cities.

- Migrants recorded with traffickers in major outlets - Nigerian route (with most traffickers found in Kumba, in the South West Region). The Sahara route (with traffickers found in Maroua in the Far North Region) and the Atlantic and global route (with traffickers mostly located in Douala).

\section{Training}

Selected youths will be trained on business management and entrepreneurship, while others will be deployed in identified technical training centers and technical cooperation, this can be 
online or onsite, but the main course will be inculcating and teaching them pan-Africanistic tendencies, just like the TEEP.

\section{Partners}

The European Union Trust Fund for Africa (EUTFA): The EUTFA was created in November 2015 during the Valetta summit to address the root causes of instability, forced displacement, and irregular migration and to contribute to better migration management (Clemens \& Postel, 2017). According to Europe Aid, the fund is worth over 3.4 Billion euros, with $88 \%$ of their contributions coming from the EU institutions and 12\% from other EU members and donor agencies. The Cameroon Government: Through creating an enabling environment for skill development, entrepreneurship, remittances and city-to-city twinning. Migrants, through concerted actions. 


\section{This will be illustrated in the diagram below:}

\section{To the EU}

- Provide enabling environment and aid policy reorientation through trust funds like increasing the EUTFA €1293 million in Sahel/Lake Chad (which Cameroon is a member) to €2000 million, since only $2 / 3$ of EFTA budget has been used so far.

- Census migrants and get real term data on Cameroonian data, in order to determine those willing to return and those that should be mainstreamed.

- Reduce aid (Europe Aid) given directly to the Cameroonian government by $30 \%$ and redirect it to young persons as start-up capital.

- Partner with Technical Cooperation in Cameroon like GIZ, SNV, AFD for skill development and training - Provide a list of European councils for future twinning with Cameroonian councils.

- Send experts in technical schools, the technical cooperations and entrepreneurship for the potential training.

\section{To the migrants}

1. Aspiring migrants

- Develop and acquire the required skill for the job market before migrating.

- Get registered in the migration database, else you get outlawed.

2. Mid-way migrants (those out of Cameroon, still struggling to enter into Europe)

- Accept the GSP scheme, to return and be trained in Cameroon and be well equipped before he/she can enter the migration database as a potential legal migrant.

3. Already settled migrants

- Promote development back home through remittances.

- Pay taxes and contribute to the development of the country in which they live.

- Be ready to share their skills back home.

\section{To the Cameroonian government}

- Create an enabling environment for startup creation, like the (http://www.cfce.cm/) and ensure that it actually takes 72 hours to create an enterprise (Checking bottlenecks) - Inclusion of specialized trainings with high demand within the migrant population like catering, logistics, nursing in technical schools and via free access e-learniing platforms. - Reduce taxes and levies on remittances.

- Foster best practices that can favor investment, by controlling corruption and mismanagement.

- Creation of a database of those already trained and ready for migration

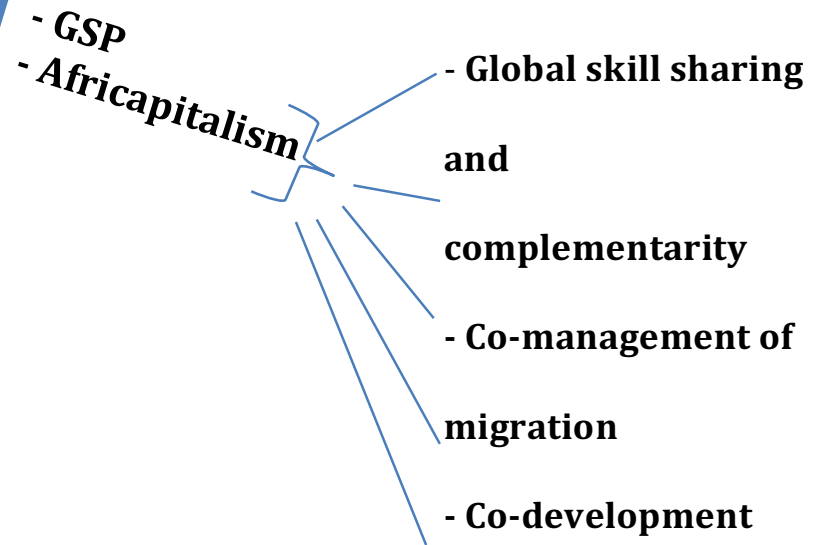

and growth

\section{Source: Author adapted}


Making migration a driver of development via aid from the above diagram can be put diagrammatically within a conceptualized framework as follows:

Action

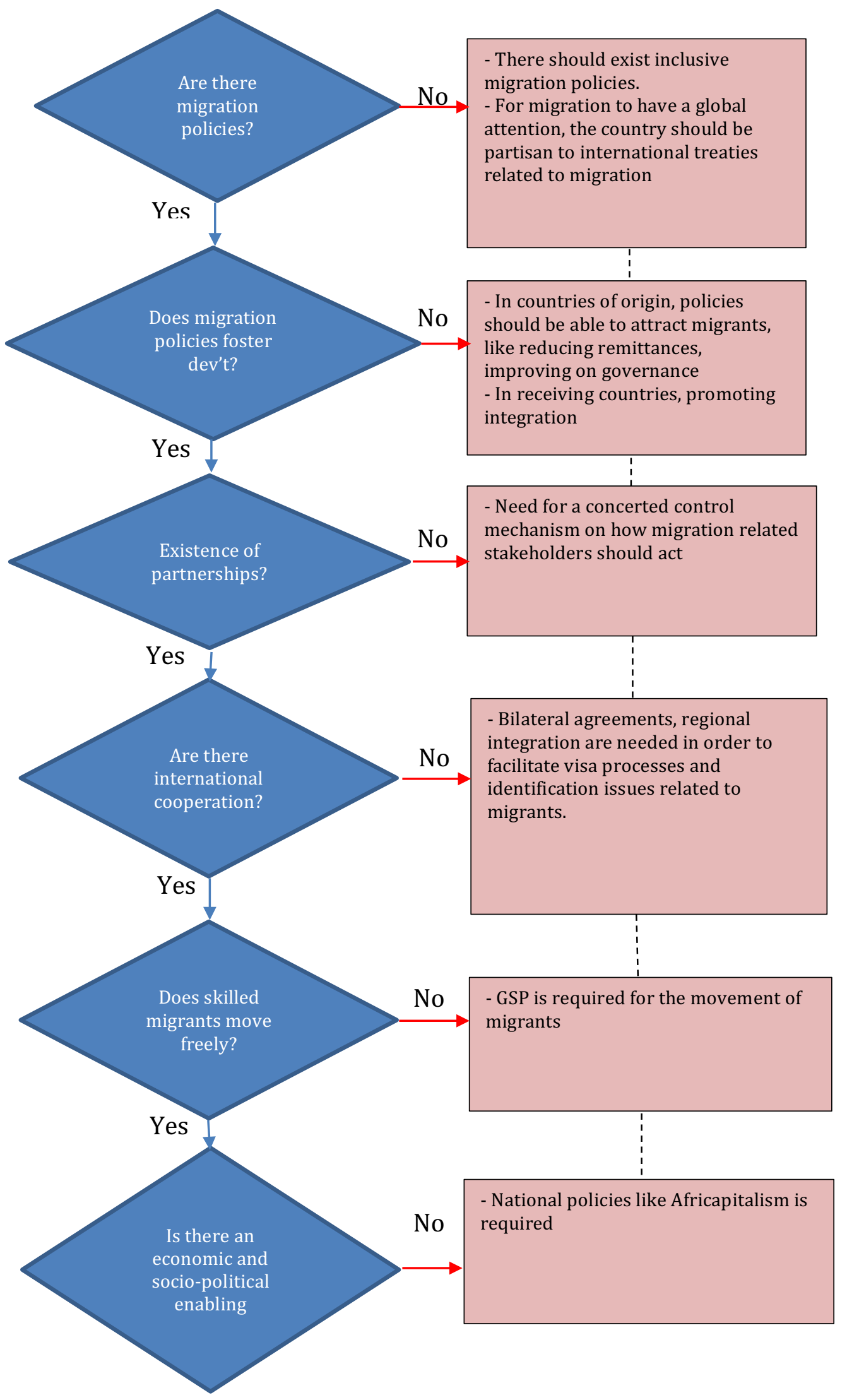

\section{Expected}

Inclusive migration policies engenders development
More partnerships and concerted effort

\section{Broad global and multinational context}

Easy movement of migrants

International participatory development

Growth and development 


\section{CONCLUSION}

Over the past 50 years, 3.2 trillion UD $\$$ has been pumped into aid, yet less developed countries like Cameroon have either regressed or are stagnant in economic development, making development to go beyond the pure 'giving to help' concept. 258 million people in the world in 2017 were considered as migrants, while others perceive them as invaders, others regard them as assets. Whatever the take, Cameroonian migrants sent 191.54 million U.S. dollars in 2014. As remittances, thereby helping enormously in development and assistance, while supplying labor force, paying taxes and participating in the socio-economic development of their host country. With these facts and figures and after having reviewed a plethora of literature, my stance is that the world is globalized and interconnected in such a way that migrants' movements between Cameroon and the EU cannot be halted, but should rather be well managed through skill partnership, labour exchange, co-development and this will be further enhanced by an African led initiative dubbed Africapitalism.

\section{References}

Acemoglu, D., \& Robinson, J. A. (2013). Why nations fail: The origins of power, prosperity, and poverty: Broadway Business.

Allen, W., Anderson, B., Van Hear, N., Sumption, M., Düvell, F., Hough, J., ... Walker, S. (2017). Who counts in crises? The new geopolitics of international migration and refugee governance. Geopolitics, 1-27.

Amaeshi, K., \& Idemudia, U. (2015). Africapitalism: A management idea for business in Africa? Africa Journal of Management, 1(2), 210-223.

Arts, K., \& Dickson, A. K. (2010). EU development cooperation: from model to symbol: Manchester University Press.

Artuç, E., Docquier, F., Özden, Ç., \& Parsons, C. (2015). A global assessment of human capital mobility: the role of non-OECD destinations. World Development, 65, 6-26.

Bank, A. D. (2006). African Development Report 2006: Aid, Debt Relief and Development in Africa: Oxford University Press.

Barro, R. J. (1991). Economic growth in a cross section of countries. The quarterly journal of economics, 106(2), 407-443.

Bermeo, S. B., \& Leblang, D. (2015). Migration and foreign aid. International Organization, 69(3), 627-657.

Berthélemy, J.-C., Beuran, M., \& Maurel, M. (2009). Aid and migration: Substitutes or complements? World Development, 37(10), 1589-1599.

Carbone, M. (2013). Between EU actorness and aid effectiveness: the logics of EU aid to sub-Saharan Africa. International Relations, 27(3), 341-355.

Clemens, M. A. (2015). Global Skill Partnerships: A proposal for technical training in a mobile world. IZA Journal of Labor Policy, 4(1), 2.

Clemens, M. A., Özden, Ç., \& Rapoport, H. (2014). Migration and development research is moving far beyond remittances. World Development, 64, 121-124.

Clemens, M. A., \& Pettersson, G. (2008). New data on African health professionals abroad. Human Resources for Health, 6(1), 1.

Clemens, M. A., \& Postel, H. M. (2017). Deterring Emigration with Foreign Aid: An Overview of Evidence from LowIncome Countries. Retrieved from

Cornelius, W. A. (2001). Death at the border: Efficacy and unintended consequences of US immigration control policy. Population and development review, 27(4), 661-685.

De Haas, H. (2008). The myth of invasion: The inconvenient realities of African migration to Europe. Third world quarterly, 29(7), 1305-1322.

Dekker, R., \& Engbersen, G. (2014). How social media transform migrant networks and facilitate migration. Global Networks, 14(4), 401-418. 
Dollar, D. (1992). Outward-oriented developing economies really do grow more rapidly: evidence from 95 LDCs, 1976-1985. Economic development and cultural change, 40(3), 523-544.

Fombad, C. M. (2000). Endemic corruption in Cameroon: insights on consequences and control. In Corruption and Development in Africa (pp. 234-260): Springer.

Gaytan-Fregoso, H., \& Lahiri, S. (2000). Foreign aid and illegal immigration. Journal of Development Economics, 63(2), 515-527.

Geddes, A. (2005). Europe's border relationships and international migration relations. JCMS: Journal of Common Market Studies, 43(4), 787-806.

Greussing, E., \& Boomgaarden, H. G. (2017). Shifting the refugee narrative? An automated frame analysis of Europe's 2015 refugee crisis. Journal of Ethnic and Migration Studies, 43(11), 1749-1774.

Gupta, S., Pattillo, C. A., \& Wagh, S. (2009). Effect of remittances on poverty and financial development in SubSaharan Africa. World Development, 37(1), 104-115.

Ikiebey, G. (2015). A Review of Extant Literature to Build the Socio-Economic Framework Africapitalism.

Lacomba, J., \& Cloquell, A. (2014). Migrants, associations and home country development: Implications for discussions on transnationalism. New Diversities, 16(2), 21-37.

Lee, E. S. (1966). A theory of migration. Demography, 3(1), 47-57.

Lucas, R. E. (2005). International migration and economic development: Lessons from low-income countries: Edward Elgar Publishing.

Lucas, R. E. (2016). Internal migration in developing economies: an overview of recent evidence. Geopolitics, History and International Relations, 8(2), 159.

Moyo, D. (2009). Dead aid: Why aid is not working and how there is a better way for Africa: Macmillan.

Oseni, J. E., \& Oseni, E. (2015). Theoretization of Africapitalism Concept.

Parsons, C. R., \& Winters, L. A. (2014). International migration, trade and aid: a survey. International Handbook on Migration and Economic Development, 65-112.

Sachs, J. (2008). The end of poverty: economic possibilities for our time. European Journal of Dental Education, 12(s1), 17-21.

Takougang, J., \& Krieger, M. (2000). African State and Society in the 1990s: Cameroon's political crossroads: Westview Press.

Thet, K. K. (2014). Pull and push factors of migration: A case study in the urban Area of Monywa Township, Myanmar. News from the World of Statistics.

Vázquez, S. T., \& Sobrao, D. G. (2016). Reshaping geographical allocation of aid: the role of immigration in Spanish Official Development Assistance. Journal of International Relations and Development, 19(3), 333-364.

Zukane, M., \& Tangang, A. T. (2017). The state of youth policies in the Central African sub region. Net Journals, III, 22. 